\title{
BLOOD FLOW AND VASOMOTOR REACTIONS IN THE FOOT IN HEALTH, IN ARTERIOSCLEROSIS, AND IN THROMBO- ANGIITIS OBLITERANS
}

\author{
By PAUL KUNKEL ANd EUGENE A. STEAD, JR. \\ (From the Thorndike Memorial Laboratory, Second and Fourth Medical Services (Harvard), \\ Boston City Hospital, and the Department of Medicine, \\ Harvard Medical School, Boston)
}

(Received for publication June 10, 1938)

In a previous communication (1) a plethysmographic method has been described for the quantitative measurement of the blood flow in the foot. In the present report the results of such measurements in normal persons and in patients with vascular disease due to arteriosclerosis or to thromboangiitis obliterans are recorded. The vasomotor reactions of the foot were also studied in normal subjects. As the hand is much less frequently involved in circulatory disturbances of the extremities, a comparison was made of the blood flow and the vasomotor reactions in the hand and foot.

\section{METHOD}

The plethysmographic method described by us (1) was used for the study of the foot, and that described by Freeman (2) for the hand. No attempt was made to establish basal conditions. The subjects reclined in the horizontal position in a quiet room, with the extremities to be tested resting comfortably in the plethysmographs at heart level. The water bath was maintained at a constant temperature for 30 minutes before readings were taken. The determinations, each of which represents an average of five tracings taken in rapid succession, were made at approximately 5-minute intervals. The figures given in this report are usually averages of two or three such determinations made after the blood flow had reached a plateau. All the values for blood flow in both the hand and foot are recorded as cubic centimeters of blood per minute per 100 cc. of tissue. Various temperatures were used for the study of the vasomotor reactions, but for the purpose of comparing the flow in the foot with that in the hand, and later for comparing the flow in the normal foot with that in the abnormal foot, the water in the plethysmograph was kept at $43^{\circ} \mathrm{C}$., a temperature easily tolerated by most subjects. After 30 minutes at $43^{\circ}$ C. spontaneous changes in the flow produced by vasoconstrictor impulses were at a minimum and the environmental temperature had very little effect on the immersed part. Throughout this report the blood flow to either the hand or the foot at $43^{\circ} \mathrm{C}$. is designated as the "maximal" flow.

In 6 subjects the surface area of the hand or the foot within the plethysmograph was determined by making a light plaster mold of the part. This mold was cut while still soft and made to lie flat by multiple incisions. The outline of the mold was traced on cardboard, which was weighed. The surface area of the hand or the foot was calculated from the known weight of $100 \mathrm{sq}$. $\mathrm{cm}$. of the cardboard.

\section{Normal subjects}

Maximal blood flow in the foot. A group of 34 normal subjects ranging in age from 17 to 67 years was selected from convalescent patients and house staff. The subjects had normal cardiovascular systems by the usual methods of clinical examination with the exception of 3 persons in the seventh decade of life who had some thickening of the radial arteries. The maximal blood flow in the 48 feet examined in this group averaged $17.1 \mathrm{cc}$., with the highest value 25.9 and the lowest $11.1 \mathrm{cc}$. The average maximal flow in the 33 feet from 23 normal males ranging in age from 17 to 67 years was $16.3 \mathrm{cc}$., with the highest 20.9 and the lowest $11.1 \mathrm{cc}$., and the average in 15 feet from 11 females between 17 and 50 years of age was $18.7 \mathrm{cc}$., with the highest 25.9 and the lowest $13.4 \mathrm{cc}$. Killian and Oclassen (3) used a plethysmograph for measuring the blood flow in the foot. Most of their figures could not be compared with ours, however, as 
the flows were reported as the increase in the volume of the foot in cubic centimeters per minute. The flow in the one subject at a comparable temperature $\left(44.8^{\circ} \mathrm{C}\right.$.), reported as cubic centimeters per minute per $100 \mathrm{cc}$. of foot, was 14.8 cc.

The variation in the maximal blood flow of the foot in different subjects was less than the variation in hand flows under similar conditions. Blood flows in 90 per cent of the feet were between 13 and $20 \mathrm{cc}$; in only one instance was the flow less than $13 \mathrm{cc}$. (Figure 1). There was no correlation between the blood flow of the foot and advancing age (Figure 2). The individual subjects showed considerable overlapping in all decades, and the differences in the average blood flow for the various decades were therefore not significant. No persons over 70 years of age with normal cardiovascular systems were avail- able for study. Pickering (4), using Stewart's method of calorimetry, determined the rate of blood flow through the hand and concluded that it declined in subjects with normal blood pressure as age advanced. He attributed this fall to sclerotic changes in the vessels of the hand. This conclusion would undoubtedly hold true for the foot if normal blood pressure were the chief criterion used in the selection of normal subjects over 50 years of age. We have not regarded as normal any person with an appreciable degree of arteriosclerosis, even though this places many symptomless subjects in the abnormal group.

In 12 normal subjects the maximal blood flow was determined in both feet simultaneously. The average difference was $1.8 \mathrm{cc}$. and the greatest difference $4.5 \mathrm{cc}$. In 2 subjects the maximal blood flow to the same foot was measured on three different days. The values in one ranged

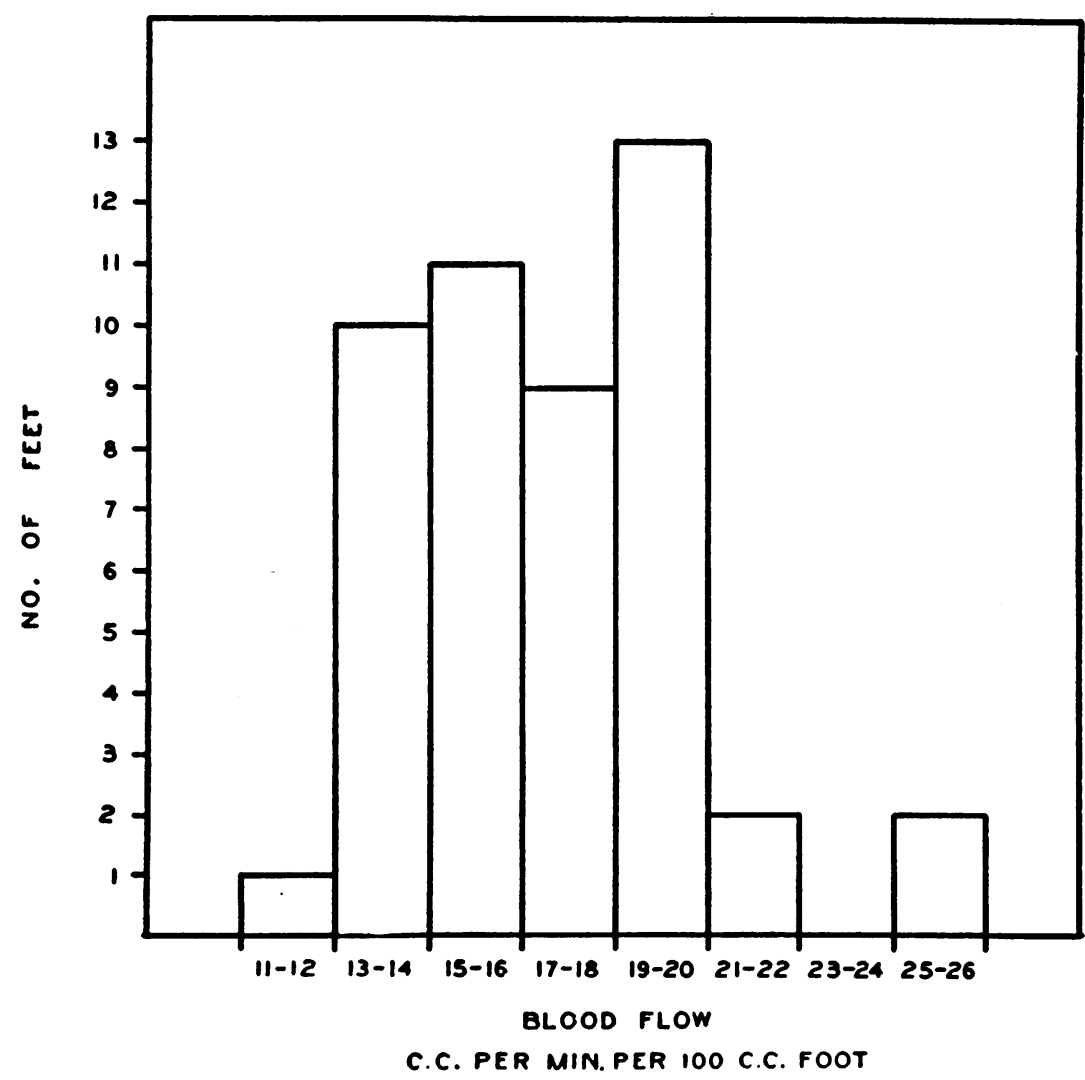

Fig. 1. Distribution of 48 Maximal Blood Flows in the Feet in 34 Normal Persons

Cubic centimeters of blood per minute per $100 \mathrm{cc}$. of foot are plotted against the number of feet. Ninety per cent of the flows are between 13 and $20 \mathrm{cc}$. 


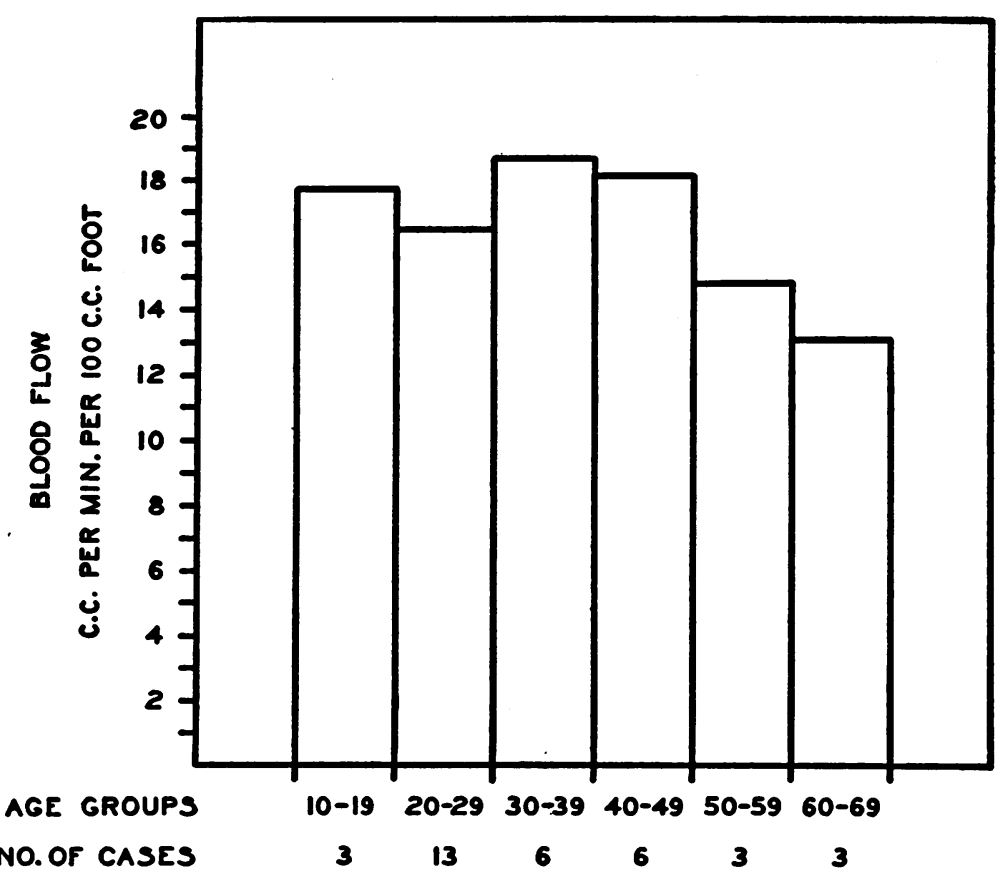

Fig. 2. Rexationship in 34 Normal Persons Between Age and Maximal Blood Flow in Cubic Centimeters Per Minute Per 100 cc. of Foor

from 13.4 to $15.7 \mathrm{cc}$. with an average of $14.6 \mathrm{cc}$., and in the other from 13.2 to $15.2 \mathrm{cc}$. with an average of $14.4 \mathrm{cc}$. In 3 other instances determinations made on the same foot on two different days showed a maximum change in blood flow of $1.6 \mathrm{cc}$. In 1 subject flows of 17.2 and $21.4 \mathrm{cc}$. were obtained in the right and the left foot, respectively. The subject was wide awake and talkative, and had an average blood pressure of $123 / 80$ and a pulse rate of 76 . Two weeks later the flows were 13.1 and 15.7 cc., respectively, the flow in the right foot still being approximately 80 per cent of that in the left foot. The patient was drowsy but not asleep, the average blood pressure was $110 / 80$, and the pulse rate 62 . The fall in flow on the second examination therefore appeared to be due to a change in cardiac output.

Simultaneous blood flow measurements in the hand and foot. Local circulatory disturbances are much more common in the foot than in the hand. This difference in incidence might be the result of (1) a special predisposition of the vessels of the foot to vascular diseases; (2) a congenitally greater blood supply to the hand, so that with equal degrees of circulatory impairment symptoms would develop first in the foot; or (3) a combination of these two factors. Therefore, in 18 normal subjects maximal blood flows were determined in the hand and the foot at the same time. The average blood flow in the hand was 32 cc. with the highest value $\mathbf{5 4 . 4}$ and the lowest $\mathbf{1 8 . 7}$ cc. ; the average blood flow in the foot was $15.7 \mathrm{cc}$. with the highest value 19.5 and the lowest $11.1 \mathrm{cc}$. The fact that the maximal blood flow in the hand per unit of tissue was twice that in the foot seemed to indicate that at least one of the factors was the congenital difference in the blood supply.

As the bones of the foot are larger than those of the hand, an attempt was made to obtain information from the literature on the relative volume of the bones of the foot and of the hand, but this was not successful. As most of the blood flow in both the hand and foot is to the skin, an indirect approach to the problem was made by expressing the flows in relation to the skin area of the extremity instead of to the volume. In 6 cases, the surface areas of the hand and foot enclosed in the plethysmographs were measured and the blood flows calculated as cubic 
centimeters of blood per minute per 100 sq. $\mathrm{cm}$. of skin. This gave the average blood flow in the hand as $32.3 \mathrm{cc}$. and the average blood flow in the foot as $24.8 \mathrm{cc}$. The blood flow to the hand calculated in this manner was 30 per cent greater than the blood flow to the foot. The subjects usually stated that at the same temperature $\left(43^{\circ}\right.$ C.) the foot felt warmer than the hand. It is possible that this was owing to the smaller blood flow in the foot and the less rapid cooling of the tissues by the blood stream.

Vasomotor reactions of the foot and the hand. The blood flow in the foot was greatly modified $(a)$ by the temperature of the surrounding water and $(b)$ by the changes in the environmental temperature of the body with the foot at local temperatures which did not cause extreme vasodilatation or constriction. At temperatures as low as from $17^{\circ}$ to $20^{\circ} \mathrm{C}$. the flow dropped to about $0.2 \mathrm{cc}$. per minute per $100 \mathrm{cc}$. of foot. The spontaneous vasomotor variations practically disappeared, but the respiratory waves, not being produced by changes in vasomotor tone, persisted. With the bath at this low temperature the vessels constricted so tightly that the flow was not detectably modified by changing the temperature of the environment of the subject or by immersing the hands in water at $45^{\circ} \mathrm{C}$. The blood flow dropped to such low levels that the small amount of chilled blood returned from the cold foot had no detectable effect on the heat regulating mechanism, and generalized sweating was easily induced by heating the body.

At temperatures of the water bath from $32^{\circ}$ to $37^{\circ} \mathrm{C}$. the blood flow to the foot was greatly influenced by the amount of generalized cutaneous vasodilatation present. In subjects without generalized vasodilatation, in a cool room the blood flow averaged about $1 \mathrm{cc}$. at $32^{\circ} \mathrm{C}$. and about $5 \mathrm{cc}$. at $37^{\circ} \mathrm{C}$. When generalized cutaneous vasodilatation was induced by blankets and hot water bottles or by immersing the hands in hot water, the blood flow rose to a level of from 8 to $12 \mathrm{cc}$. The blood flow in the foot at $37^{\circ} \mathrm{C}$. caused by heating the body was rarely greater than one-half that produced by a local heat of $43^{\circ} \mathrm{C}$. There was, however, considerable individual variation and in 1 subject heating the body produced such marked cutaneous vasodilatation that the blood flow at $37^{\circ} \mathrm{C}$. nearly equaled that at $43^{\circ} \mathrm{C}$. In both the hands and the feet, at $32^{\circ} \mathrm{C}$., the blood flows were about $1 \mathrm{cc}$. in the absence of generalized vasodilatation. When the body was heated, the blood flow in the hand usually increased much sooner than in the foot. This is in accord with the common observation of warm hands and cold feet.

The vessels of the feet responded by vasoconstriction to psychic influences and pinching the skin in essentially the same manner as those of the hand. No effort was made to quantitate the stimuli, or to determine whether or not reflex vasoconstriction could be limited to either the foot or the hand by the use of appropriate stimuli applied to various points on the body. At $43^{\circ}$ C. the vessels of the foot and of the hands of different subjects showed marked variation in the response to the pinch stimulus. Some subjects lost the pinch response completely, while in a few it was as active as at $37^{\circ} \mathrm{C}$.

In order to determine whether the local heat of $43^{\circ} \mathrm{C}$. caused maximal dilatation of the vessels of the foot, the heat stimulus was reinforced by a 5 -minute period of arterial occlusion. Wide blood pressure cuffs were applied just above the collecting cuff and just below the knee. These were suddenly inflated from a large reservoir to a pressure of $290 \mathrm{~mm}$. Hg. In each instance the arterial occlusion was complete, as was shown by the absence of any increase in foot volume. Measurements of blood flow were made immediately following release of the pressure, at a time when the vascular dilatation caused by the reactive hyperemia should have been at its height. In 2 subjects there was no increase in blood flow; in a third it increased from 22.9 to $26.4 \mathrm{cc}$. Thus the blood flows obtained with the foot bath at $43^{\circ} \mathrm{C}$. are nearly maximal.

The tracings of the blood flow from the foot at $43^{\circ} \mathrm{C}$. showed a constant increase in volume for a longer time than those from the hand at the same temperature and were therefore easier to interpret. This difference in behavior of the hand and foot curves was not owing to any difference in the reaction of the vessels to heat, but rather to technical differences. In the hand, at temperatures from $43^{\circ}$ to $45^{\circ} \mathrm{C}$., as noted by Capps (5) the amount of venous distention ob- 
tained by a given degree of venous obstruction was frequently less than at lower temperatures $\left(37^{\circ} \mathrm{C}.\right)$. The veins, even though dilated, remained full as the result of the rapid inflow of arterial blood. The amount of available venous space for the increase in the hand volume when the collecting pressure was applied was small, and the tracings were straight for only a short distance. This difficulty has not been encountered in the foot. The slower blood flow prevented the veins from becoming engorged to as great a degree as in the hand, and the greater hydrostatic pressure resulting from the higher column of water in the foot plethysmograph, caused the veins of the foot to empty more rapidly. That these factors were operative is indicated by experiments with the hand at $43^{\circ}$ in which the apparent decrease in the amount of venous distention for a given degree of venous obstruction was increased over that present at $37^{\circ}$ by raising the hydrostatic pressure in the hand plethysmograph to the same level as that used in the foot plethysmograph. The curves of the blood flow in the hand likewise became straighter for a longer distance.

The identical response of the vasomotor system in the hand and foot was also demonstrated by the simultaneous drop in the base line of the tracings of the hand and foot when vasoconstriction was induced by a deep inspiration (Figure $3 A$ ). Bolton, Carmichael, and Stürup (6) have called attention to this reflex in the toes and the fingers. On the other hand, the usual respiratory waves that were frequently visible on a slow drum even at low temperatures $\left(17^{\circ} \mathrm{C}\right.$.) were not of vasomotor origin. Figure $3 B$ shows these waves in a subject breathing more deeply than normally. The elevations in the hand waves occurred at the same time as the depressions in the tracings of the foot. During inspiration, the negative pres-

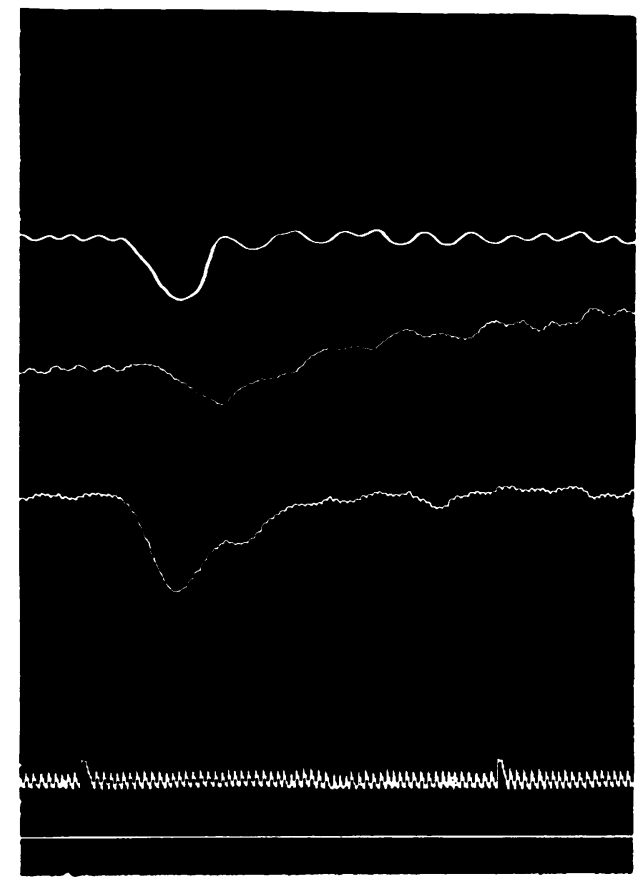

A

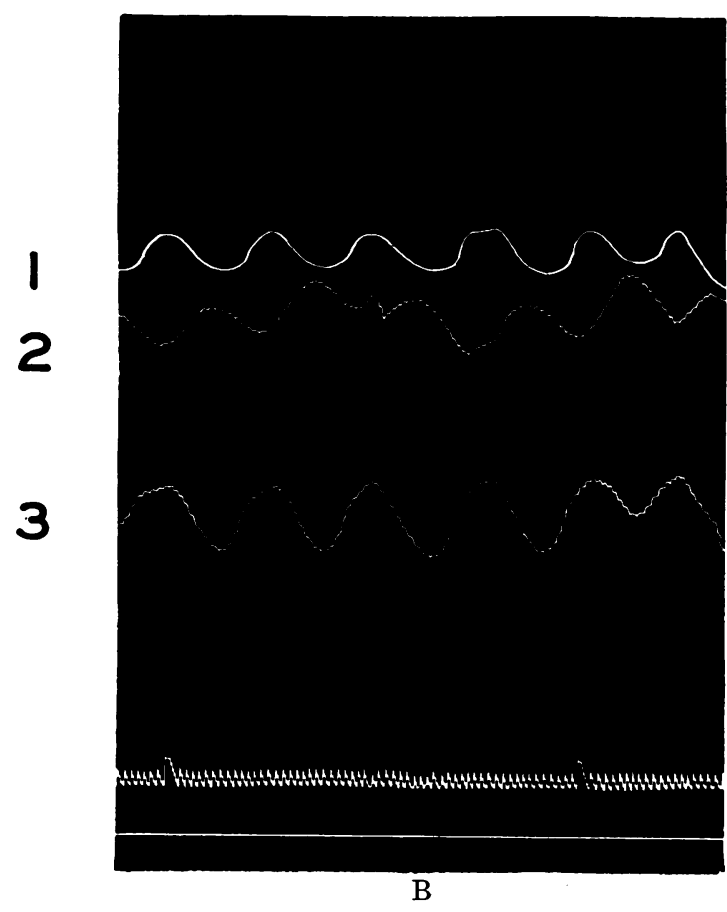

Fig. 3A. Vasoconstriction in Both Hand and Foot Following Deep Inspiration. (1) Respiratory Tracing with Down Stroke Indicating Inspiration. (2) Tracing from Foot. (3) Tracing from Hand. In (2) and (3) a Downward Deflection is Caused by a Decrease in the VOLUME OF THE PART

Fig. 3B. Respiratory Waves from Hand and Foot Tracings Exaggerated by Moderately Deep BREATHING

During inspiration the foot increases and the hand decreases in volume; during expiration the foot decreases and the hand increases in volume. 
sure in the thorax was increased; the venous pressure in the arm fell with a resulting decrease in the volume of the hand. At the same time the intra-abdominal pressure rose, the venous pressure in the leg increased, and the foot increased in volume. During expiration, the volume of the hand increased and the volume of the foot decreased. These shifts again followed the changes in intrathoracic and intra-abdominal pressures. Lluesma Uranga ( 7 ) called attention to the fact that these waves were reversed in the upper and lower extremities but offered no explanation for the phenomenon.

\section{Patients with arteriosclerosis and thromboangiitis obliterans}

Twenty-one feet with arteriosclerosis of the vessels of the foot were studied in 13 subjects.
A summary of the relevant clinical data and of the blood flows is given in Table I. No pulsations of the posterior tibial arteries were palpable in these subjects. In 1 of the 3 cases in whom the dorsalis pedis pulsations were equal bilaterally the vessel walls were palpable and sclerosed; in the other 2 there was evidence of sclerosis of the radial, brachial, and cerebral vessels. The 10 feet without symptoms and without trophic disturbances had an average maximal flow of 8 cc. In the 11 feet with either symptoms or trophic disturbances the flow averaged $4.8 \mathrm{cc}$.

Thus, in general, the maximal flow to the foot can be decreased 50 per cent without producing any signs or symptoms. When the maximal flow is decreased to approximately one-third the normal value, or to the level of $5 \mathrm{cc}$. or below, symptoms and trophic changes are apt to occur.

TABLE I

Clinical data and maximal blood flow in the feet in 13 patients with arteriosclerosis of the vessels of the foot

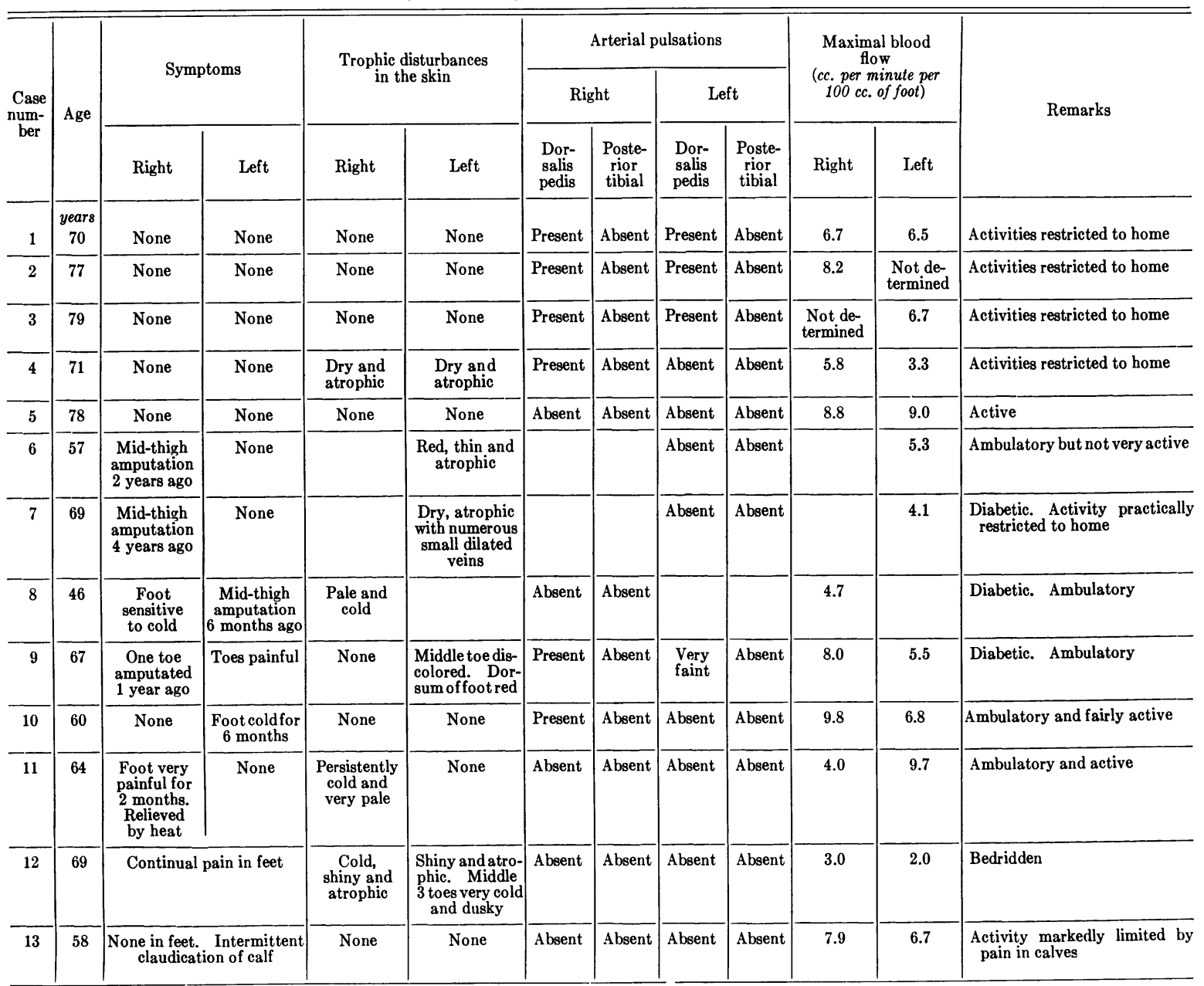


The exact level at which these appear is influenced to a large extent by the general activity of the subject and by the exposure to cold and trauma to which the foot is subjected. Thus no symptoms were present in Cases 1 through 4 in whom there was an average blood flow of 6.2 cc. The activities of this group of subjects were restricted to their homes through weakness and senility. In the other 9 feet with blood flows under $7 \mathrm{cc}$. only 3 were symptomless and in each patient the range of activities was greatly limited, in 2 by mid-thigh amputations and in the third by intermittent claudication in both calves.

The patient in Table I with intermittent claudication in both calves had reduced blood flow in both feet. Studies were also made on a 55-year old man with a typical history of intermittent claudication in the right calf of 3 years' duration but with no symptoms in the left calf. He complained also of cold, purple feet on exposure to low temperatures. The feet appeared normal at room temperature $\left(22^{\circ} \mathrm{C}\right.$. $)$. Both dorsalis pedis and posterior tibial pulsations were present though they were somewhat less forceful on the right. The maximal blood flow in the right foot was $14.9 \mathrm{cc}$. and that in the left $26.3 \mathrm{cc}$. The change in color and the pain at low temperature were probably caused by vascular spasm. It was assumed that the blood flow to the calf muscles on the right had been curtailed to a much greater extent than the flow to the right foot, which was still well within normal limits though decreased for this particular individual, as was shown by the unusually rapid blood flow in the left foot. Thus if the arteriosclerotic changes occur in localized areas, or if adequate collateral circulation is established, severe intermittent claudication may occur in the calf while the blood flow in the foot is still as rapid as in many normal individuals.

Table II gives the clinical data and blood flow in the feet of 5 cases of thromboangiitis obliterans. The diagnosis seemed to be definitely established in the first 4 cases. The etiology of the vascular disease in the fifth case was in some doubt but, in the absence of any peripheral sclerosis demonstrable either by palpation or by $\mathrm{x}$-ray examination of the lower extremities, it has been included in the group with thromboangiitis obliterans. When the vessels of the feet are involved in this disease the symptoms and trophic disturbances are produced at about the same level of blood flow as in the arteriosclerotic group. Thus the 2 feet with blood flows below $6 \mathrm{cc}$. showed either trophic disturbances or sensitivity to cold. As in the arteriosclerotic group, intermittent claudication of the calf may be incapacitating while the collateral circulation is sufficient to keep

TABLE II

Clinical data and maximal blood flow in the feet in 5 patients with thromboangitis obliterans

\begin{tabular}{|c|c|c|c|c|c|c|c|c|c|c|c|c|}
\hline \multirow{3}{*}{$\begin{array}{c}\text { Case } \\
\text { num- } \\
\text { ber }\end{array}$} & \multirow{3}{*}{ Age } & \multirow{2}{*}{\multicolumn{2}{|c|}{$\begin{array}{l}\text { Duration and severity } \\
\text { of intermittent } \\
\text { claudication in } \\
\text { calves }\end{array}$}} & \multirow{3}{*}{$\begin{array}{c}\text { Distance } \\
\text { before } \\
\text { pain } \\
\text { halts } \\
\text { patient }\end{array}$} & \multirow{2}{*}{\multicolumn{2}{|c|}{$\begin{array}{l}\text { Symptoms and signs of } \\
\text { trophic disturbances in foot }\end{array}$}} & \multicolumn{4}{|c|}{ Arterial pulsations } & \multirow{2}{*}{\multicolumn{2}{|c|}{$\begin{array}{c}\text { Maximal } \\
\text { blood flow } \\
\text { (cc. per minute per } \\
100 \text { cc. of foot) }\end{array}$}} \\
\hline & & & & & & & \multicolumn{2}{|c|}{ Right } & \multicolumn{2}{|c|}{ Left } & & \\
\hline & & Right & Left & & Right & Left & $\begin{array}{l}\text { Dor- } \\
\text { salis } \\
\text { pedis }\end{array}$ & $\begin{array}{c}\text { Poste- } \\
\text { rior } \\
\text { tibial }\end{array}$ & $\begin{array}{l}\text { Dor- } \\
\text { salis } \\
\text { pedis }\end{array}$ & $\begin{array}{c}\text { Poste- } \\
\text { rior } \\
\text { tibial }\end{array}$ & Right & Left \\
\hline 1 & $\begin{array}{c}\text { years } \\
31\end{array}$ & $\begin{array}{l}5 \text { years; } \\
\text { severe }\end{array}$ & $\begin{array}{l}5 \text { years; } \\
\text { severe }\end{array}$ & $\begin{array}{r}\text { yards } \\
200\end{array}$ & None & $\begin{array}{c}\text { Skin dis- } \\
\text { colored and } \\
\text { pigmented }\end{array}$ & Absent & Absent & Absent & Absent & 10.1 & 4.9 \\
\hline 2 & 32 & $\begin{array}{l}10 \text { years; } \\
\text { severe }\end{array}$ & $\begin{array}{l}10 \text { years; } \\
\text { severe }\end{array}$ & 200 & $\begin{array}{l}\text { Sensitive } \\
\text { to cold. } \\
\text { Dusky red }\end{array}$ & $\begin{array}{l}\text { Very sensi- } \\
\text { tive to cold. } \\
\text { Ulcer on } \\
\text { one toe }\end{array}$ & Absent & Absent & Absent & Absent & 5.8 & $\begin{array}{l}\text { Not deter- } \\
\text { mined }\end{array}$ \\
\hline 3 & 48 & $\begin{array}{l}9 \text { years; } \\
\text { severe }\end{array}$ & $\begin{array}{l}\text { No dif- } \\
\text { ficulty }\end{array}$ & 1000 & None & None & Absent & Absent & Present & Present & 12.8 & 24.9 \\
\hline 4 & 49 & $\begin{array}{l}25 \text { years; } \\
\text { severe }\end{array}$ & $\begin{array}{l}25 \text { years; } \\
\text { severe }\end{array}$ & 100 & None & $\begin{array}{l}\text { Ulcer on toe } \\
\text { and ankle }\end{array}$ & Absent & Absent & Absent & Absent & 6.8 & $\begin{array}{l}\text { Not deter- } \\
\text { mined }\end{array}$ \\
\hline 5 & 57 & $\begin{array}{l}\text { Ques- } \\
\text { tionable }\end{array}$ & $\begin{array}{l}2 \text { years; } \\
\text { severe }\end{array}$ & 200 & None & None & Absent & $\begin{array}{l}\text { Very } \\
\text { faint }\end{array}$ & Absent & Absent & 11.0 & 6.2 \\
\hline
\end{tabular}


the blood flow in the foot within average normal limits. When only one leg is involved, however, this flow can be shown to be low for that particular individual by comparing it with the normal foot. In the cases of arteriosclerosis and thromboangiitis obliterans no determinations were made on feet with open ulcers. As a rule the patients tolerated the local heat quite well, although in 4 cases the water was allowed to cool down to $42^{\circ} \mathrm{C}$. because the heat caused local discomfort. In no case did the skin show any ill effects from the prolonged soaking in hot water.

\section{DISCUSSION}

The plethysmographic method of studying the circulation in the foot has an advantage over the indirect methods, such as skin temperature measurements, reactive hyperemia, histamine test, and toe plethysmograph tracings, for blood flow is measured directly and recorded as cubic centimeters of blood per minute per $100 \mathrm{cc}$. of tissue. Therefore, direct comparison can be made not only between blood flow in the normal and the abnormal foot, but also between the blood flow in the foot and in other parts of the body. The method offers a quantitative means for following the natural course of vascular disease in the foot and for studying the efficacy of various forms of therapy. The production of the maximal blood flow in the foot by local heat obviates the necessity for careful regulation of the room temperature. As the direct heat overcomes the vascular spasm, spinal anesthesia or nerve block is not necessary for the evaluation of the degree of vascular change in those cases in whom vasodilatation is not produced by heating the body. The plethysmographic method has the disadvantage, under certain conditions, of recording the blood flow in the entire foot. Thus, with the pathology localized in one toe, the readings would be within normal limits. It may be asked whether the circulation is measured in those cases in whom the blood is brought to the foot through small vessels in which the pressure may drop to much lower levels than in the larger vessels ordinarily supplying the foot with blood. The occurrence of blood flows of from 9 to $13 \mathrm{cc}$. in cases without palpable pulsation in the vessels of the foot, and the correlation of signs and symptoms with similar levels of blood flow in cases with arteriosclerosis and thromboangiitis obliterans, indicate that the collateral flow is measured when present. In these measurements of total blood flow in the foot no distinction is made between blood flowing through capillaries and that flowing through arteriovenous anastomoses. Thus the total blood flow may not always indicate accurately the amount of blood available for nourishing the tissues.

\section{SUMMARY AND CONCLUSIONS}

1. Measurements of the blood flow in the foot in health, in arteriosclerosis, and in thromboangiitis obliterans were made under standard conditions by the plethysmographic method. The flow was recorded as cubic centimeters of blood per minute per $100 \mathrm{cc}$. of tissue.

2. The blood flow to the foot reached a constant level after 30 minutes at $43^{\circ} \mathrm{C}$. The flow at this temperature has been designated as the "maximal" flow.

3. The average maximal blood flow to the foot in normal persons was $17.1 \mathrm{cc}$., with the highest 25.9 and the lowest $11.1 \mathrm{cc}$. Ninety per cent of the flows were between 13 and $20 \mathrm{cc}$. The average difference in the maximal flow in the right and left foot was $1.8 \mathrm{cc}$.

4. The maximal blood flow in the foot showed no appreciable decrease with age (17 to 67 years) in the presence of a normal cardiovascular system.

5. The average maximal blood flow in the hand per equal volume of tissue was twice that in the foot. When calculated in relation to skin area the maximal flow in the hand was 30 per cent greater than that in the foot.

6. The vasomotor reactions of the hand and foot were qualitatively similar. The rhythmic respiratory waves observed during normal breathing resulted from the changes in venous pressure associated with respiration and were not of vasomotor origin. A deep inspiration, however, induced constriction of vasomotor origin in both the hand and the foot.

7. In arteriosclerosis and thromboangiitis obliterans the maximal blood flow to the foot was reduced 50 per cent without symptoms or trophic disturbances. When the flow was reduced to one-third the normal value, or to the level of $5 \mathrm{cc}$. 
or below, symptoms or trophic disturbances usually occurred.

8. In both arteriosclerosis and thromboangiitis obliterans severe intermittent claudication in the calf was in some cases incapacitating, though the blood flow in the foot was as great as in many normal individuals. Thus the presence of an adequate supply of blood to the foot did not eliminate the possibility of obliterative disease involving the vessels of the calf muscles.

The authors wish to express their sincere appreciation to Dr. Soma Weiss, for his many helpful suggestions and guidance in this work; and to Miss Sophia M. Simmons, for her technical aid. They wish also to thank Dr. Edward A. Edwards for sending them two cases of thromboangiitis obliterans.

\section{BIBLIOGRAPHY}

1. Stead, E. A., Jr., and Kunkel, P., A plethysmographic method for the quantitative measurement of the blood flow in the foot. J. Clin. Invest., 1938, 17, 711.

2. Freeman, N .E., The effect of temperature on the rate of blood flow in the normal and in the sympathectomized hand. Am. J. Physiol., 1935, 113, 384.

3. Killian, J. A., and Oclassen, C. A., Comparative effects of water baths and mustard baths at varying temperatures on the rate of peripheral blood flow in man. Am. Heart J., 1938, 15, 425.

4. Pickering, G. W., The peripheral resistance in persistent arterial hypertension. Clin. Sc., 1936, 2, 209.

5. Capps, R. B., A method for measuring tone and reflex constriction of the capillaries, venules and veins of the human hand with the results in normal and diseased states. J. Clin. Invest., 1936, 15, 229.

6. Bolton, B., Carmichael, E. A., and Stürup, G., Vasoconstriction following deep inspiration. J. Physiol., 1936, 86, 83.

7. Lluesma Uranga, E., El método pletismográfico en la determinación de la capacidad funcional de las obstrucciones y espasmos arteriales de los miembros. Crón. méd., Valencia, 1934, 38, 415. 